\title{
The Evolution of Botanical and Herbal Medicine in Islamic Civilization
}

\author{
Gholam Reza Montazeri, Yaddollah Sepehri \\ Islamic Sciences, Gorgan University of Agricultural Sciences and Natural Resources, Gorgan, Golestan Province, Iran \\ Email: gholamreza_montazeri@yahoo.com
}

How to cite this paper: Montazeri, G.R. and Sepehri, Y. (2019) The Evolution of Botanical and Herbal Medicine in Islamic Civilization. Open Journal of Ecology, 9, $35-42$.

https://doi.org/10.4236/oje.2019.93004

Received: February 14, 2019

Accepted: March 16, 2019

Published: March 19, 2019

Copyright $\odot 2019$ by author(s) and Scientific Research Publishing Inc. This work is licensed under the Creative Commons Attribution International License (CC BY 4.0).

http://creativecommons.org/licenses/by/4.0/

\begin{abstract}
Botanical science and medicinal plants are shaped by the translation movement in Islamic civilization and in the fifth century (AH), through the development of specialized media and the commencement of scientific and research trips, its foundations are strengthened. In the sixth and seventh centuries $(\mathrm{AH})$, the development of the first botanical encyclopedias, the introduction of objective observations and practical experiences on theoretical issues, the prosperity of this science was provided by writing comprehensive books on medicinal plants and in the eighth century (AH). Like other intellectual and transcendental sciences, the loss of the past lost due to the decline of the writings and led to a recession. The Muslims played a role in preserving and building the body of knowledge of the Greek, Roman times. In fact, they gained this science from the distant paths. In the history of medicine, Islamic medicine is the science of medicine developed in the Islamic Golden Age, and written in Arabic, the lingua franca of Islamic civilization. In this article, we try to investigate the effect of Islamic scholars on the dynamics of medicinal herbs and the continuation of Muslim researches and innovations in the field of botany and medicinal herbs.
\end{abstract}

\section{Keywords}

Islamic Civilization, Evolution, Botanical, Medicinal Herbs

\section{Introduction}

In Islamic culture, efforts have been emphasized for the study of science in particular, thinking, and exploration in the natural landscape of the earth with the aim of studying the wonders of creation and divine verses. Accordingly, Muslim scholars have tried to get curiosity and the desire to understand natu- 
ral resources and vegetation, to observe the divine verses, and they have facilitated the suffering of scientific adventures in the Islamic world [1].

Muslim scholars commissioned botanical studies due to the need for research on medicinal plants with the aim of responding to medical needs and contributing to the physical and mental health of the community and they created the context of the advent of pharmacology in Islamic civilization. In the knowledge that its English equivalent is pharmacology, it was expressed from the recognition of plants and the determination of the geographical area of these species of Chinese, Hindi, Roman, Iranian, as well as from the growing season of the plants.

They learned how to make mineral chemicals from the Chinese and then introduced it to the West. The most important source of Muslims in the field of medical materials is the text of Jami bin Biaar (dated $1248 \mathrm{AD}$ ), which lists more than 2000 materials, including many plants. In fact, the doctors who participated in the Crusades introduced Islamic medicine to Europeans. Also, in the Middle Ages, plant trade was a huge international trade [2].

The encouragement of the leaders of Islam from medicine and the recruitment of Christian and Jewish doctors in the caliphate system, on the one hand, and the need of the Islamic community, on the other hand, led the Muslims to come to medicine and they would work in this field and after the translation stage, to compile medical books and they wrote their innovations [3].

With another subject in Islamic history and civilization, we can mention that Muslims are the leading advocates in pharmaceutical science with strong reasons; because they had a lot of attention to the recognition of medicinal plants and they were careful to look like one of the branches of medical science, and, finally, they were able to create the important scientific development in this field and provide valuable services by recognizing the plants.They identified medicinal herbs from India and elsewhere in the United States in the treatment of illnesses and because of the need for botanicals for the syrups and potions and spices [4].

The intellectual heritage of the ancient generation of Islamic scholars is rich in diversity. But those works of interest can be divided into two parts, divided into a general category [5].

\subsection{General Resources}

The purpose of these sources is the works that are not devoted to the natural history, but in terms of necessity, along with other topics of interest to the authors, of natural resources, vegetation or properties of herbal medicines, including: General history such as: Tabari's history, works by Ibn Maskouyeh, works in which history is interwoven with natural history, such as the works of Abu Rihan Bironi, Siouti, and geographic texts such as Nazeh al-Mushtaqh Edrisi's book and ...

\subsection{Exclusive Books}

Appendices refer to a specific subject of natural history and botany. Among 
them: al-Fahlah al-Nahtatiyah, Ibn Wahshieh, book al-Fahla ibn Awam, Advieh Mufrada Ghobagh, Advieh Mofradh, Ibn Beatar ...

\section{The evolution and stages}

In this study, we will introduce a comprehensive introduction of outstanding works based on the historical and evolutionary stages to provide a clear picture of the evolution of botanical sciences and medicinal plants in Islamic civilization and to learn more about the contribution and role of the creators of this work in the development and development of the realm knowledge.

\section{Third and Fourth Grade (AH). Foundation Period and Scientific Prosperity}

The beginning of the scientific and technological evolution of botanical and medicinal plants can be sought in the golden age of the flowering of Islamic civilization, the period of the Abbasid caliphate and the influence of Rijal with Iranian culture in their political and social realms.

The period that formed with the translation of the sciences from various Greek, Syriac, Hindi to Arabic, and thinkers gave rise to the growth and development of various branches of intellectual science, especially natural history, botanical studies with the longstanding efforts of the Islamic thinkers. One can refer to the very effective role of Hunan ibn Isaac in the translation of Dassfor Yiddis and Galenos in Syriac [6].

The significance of Hunin's translations in this transformation is such that, in Leclerc's opinion, if Hunin had not created this scientific movement in the East, there would be no one to do this or to be so sure and so active. As a result of this scientific movement, a new window opened up to Muslim thinkers and provided background to botanical studies and research in Islamic civilization.

The important thing is that the botanists and natural history enthusiasts were not convinced that the present situation, while benefiting from valuable scientific experiences and other civilizations, eventually turned into a reference point for other nations, by expanding the scientific domain of this knowledge and Enhancement, and the pioneering of a more complete solution [7].

In the words of one of the foreign writers who had numerous studies in the field of pharmacy, he placed Muslims among the first founders of pharmacy science, the first providers of pharmaceutical practices and initiated the creation of a pharmacy in today's fashion [8].

Among the other benefits of botanical research and the properties and functions of medicinal herbs among Muslims, we can mention the crucial role of medicinal herbs in the health and physical and mental health of the people. Muslim scholars oversaw the phases of production and testing of pharmacists in order to ensure their ability and firmness to professional ethics, as during the caliphate of Rashid, the pharmacists and physicians, they were able to carry out this mission, and they presented the reports of investigations your own [9]. 


\section{The Fifth Century (AH). The Period of Development and Promotion of This Botanical Science}

The fifth century can be considered the beginning of the growth and flourishing of botanical science, especially in Andalusia. The period provided was the foundation of outstanding scientific scholarship in Islamic civilization and had a profound effect on the effects of Evadar on the advent of scholars and scholars on scientific trips and on the acquisition of objective experiences and observations. During this period, the researchers and authors of Andalusia enjoyed a high status, and the case attention was drawn to the outstanding professors in these techniques, due to the writing of a series of related works on agriculture and botany.

During this period, the Muslims put up on their agenda the establishment of excellent water networks, the construction of Iranian-style gardens in Spain. Benefit from the varied Andalusian and Moroccan plants, along with the existence of excellent irrigation networks that have remained in some areas up to now, provided a ground for the compilation of botanical work [1] [4].

\section{Sixth and Seventh Centuries (AH). Flourishing and Peak}

Botanical science and medicinal herbs reached the peak of the scientific flourishing in their evolution, in these two centuries, and due to numerous botanical science innovations and achievements, many scientists became interested in the botanical field. One of the achievements of this period and the prevailing attributes of the preceding period is the expansion of scientific trips, the writing of the most basic and strongest treatises related to botanical and medicinal plants, the development of the first encyclopedias of medicinal plants, illustration and drawing of different stages of plant growth with research goals and optimal use of the results of personal experiences and observations in describing and describing the plants.

\section{The Eighth Century (AH). Period of Depression and Death}

Although books were published in botany, books, however, declined in this period, especially in science and natural history. Accordingly, this century can be considered a record period of scientific efforts of Muslims in various fields, including botanicals, and medicinal plants.

\subsection{Researches and Featured Books}

However, there are translations from Islamic scholars that clearly show the impact of medical work in European countries. For example, Razi's books and Abu Ali Sinai's law. So, given the importance of the subject, we are dealing with the evolution of Islamic medicine and herbs by mentioning famous books in that particular period.

These books deal with the introduction of plants and the use of their judgment, and it is determined that each scientist has introduced the number of 
plants and the new plants in Islamic medicine were the result of which scientists in which period.

Stage 1: Third and fourth grade $(\mathrm{AH})$ :

1) The Book of Al-Nabat, Abu Hanifa Dinvari (282 AH)

The author of this great and valuable work has compiled everything in the Arabic language about the plants. Most often, these terms and botanical terms are described in a lexical manner, but sometimes also introduces a variety of plants in a scientific manner.

The work has a lexical aspect, but because of its importance, attention has always been paid to the attention of doctors and botanists.

2) Ferdos al-Hikmah. Abolhassan Ali ibn Rabbn al-Beri (around $112 \mathrm{AH}$ ):

This book is among the first comprehensive medical works and also contains important articles on pharmacology, and spice.

3) Al-Havi (al-Havi fi al-Talab) Abu Bakr Muhammad ebn. Zakaria Razi Razi, (123 AH):

This valuable medical effect has examined about 366 plants.

4) Al-Fahla al-Nabteyah. Ibn Wahshieh (Abu Bakr Ahmad ibn Ali Bin Qays):

Al-Fahlah's book has world renown due to its importance, and many of its topics are devoted to plants, planting practices, irrigation, maintenance, pest control, root and stem properties, leaf and fruit, and related agricultural issues.

The author used the first Arabic name of the Arabic names of plants and, in many cases, Greek, Nepothean, and Persian names.

5) Cidane. Abu Rayhan Exterior (162 AH):

Cidane is a book written by Abou Rihān in pharmacology. This effect is due to the categorization of drugs and the way in which they are used. The differences between the properties of each plant and the Greek, Syriac, Arabic and Iranian names of drugs, Introduction the book is a cidny with five chapters, each dedicated chapter. It is a specific topic of the herbs. The main body of the book consists of about 366 medications based on the alphabetical list and the writer's effort to provide Arabic, Greek, Persian, Hindi and Hebrew names along with their synonyms.

6) Law Abu Ali Hussein bin Abdullah bin Sina (428 AH):

The law of Ibn Sina has put all the medical books in its domination, for centuries and centuries, both in Islamic lands and in Middle Eastern Europe.The validity of this work was so great that in the medical circles of the Islamic world, which the military system says: If Hippocrates and Galenus were alive, it was possible to prostrate before this book.

\section{Stage 2: Sixth and seventh centuries $(\mathrm{AH})$ :}

1) Al-adwei Al-Mafrud Book. Abu Ja'far Ahmad ibn Muhammad al-Ghafqi

The book can be named as one of the best and most accurate compilations and botanical samples in terms of the combination of botany and medicine and the significant relationship between botanical and medicinal plants [1].

2) The Book of Al-Fahlah, Ibn al-Awam Andalus (583 AH) 
The Book of Al-Fahlah is one of the most important medieval treatises that this book is about agriculture and in thirty-four chapters. This book deals with agriculture and animal husbandry.

The comprehensiveness and practical aspects of this book has improved its technical and scholarly value and it has become a privileged book on agriculture.

Ibn Awam had a keen interest in agriculture and its issues and often used his personal experiences in cultivation. He paid for such topics as explaining and explaining the types of soil, types of fertilizers, types of transplantation, various types of water and methods of plowing and their irrigation practices. One of the main goals of Ibn Awam's writing of this work has been through the training of farmers, the ground for raising the value of land.

3) Al-Nakhl's book. Abdul Latif Baghdadi:

Baghdadi was among the scholars who have more than 100 treatises on all subjects, including botanicals. Including the Book of Al-Nahl, the book of the Islamic Revolutionary Guard, published in Egypt, which includes the observations of the author on botanical matters [6].

4) Aladwei Al-Mafrud Book. Rashid alDin Abu Mansur ibn Abi al-Fazl ibn Ali Suri (616 AH):

Ibn Suri (botanist and physician) enjoyed great value in botanical field due to his efforts and his book was considered and used as a reference in pharmacology among European and Muslim scholars. Accordingly, a number of researchers named him the founder of a new scientific botanist. In his scientific career, he is more concerned with his exact experimental approach to the study of medicinal herbs.

According to Ibn Abi Ishiya, he included a two-step general approach: the search and identification of medicinal and medicinal herbs traveling to different regions of Jebel-Lebanon, Iraq, Armenia, Antakya and Anatolia, and recording the stages Different plant growth. This book is exquisite and in the Encyclopedia of Medicinal Plants that has provided a great service to enthusiasts and researchers in recognizing plants because of colorful and accurate images.

5) Book of Al-Jame lesefat Ashtat AL-Nabat. Abu Abdullah Muhammad ibn Abdullah bin Idrisi (646 AH)

He is known as Sharif Idrisi, a geographer, historian, botanist and adelist of Andalusia whose reputation is for the book of Naseh al-Mushtaq. The book was written with the purpose of identifying seven climates and within fifteen. Nevertheless, his valuable work is reminiscent of medieval and botanical medicine.

\subsection{The History of Medicine and Herbal Plants in Iran}

In Iran, as one of the seven Asian countries, there are the most medicinal herbs, and this tendency to medicinal plants and we are witnessing a growing trend in the use of these herbal medicines and the revival of traditional medicine. According to available statistics there are more than 130 herbal remedies in Iran. For a very long time, plants have played an important role in the treatment of 
many diseases especially in the East region countries [10].

Iran is an ancient country in usage of herbal plants and there are documents showing Persians were pioneers in applying plants for medicinal purposes [11]. Evidence in many European countries show herbal medicine is very popular. In Iran, some continuous projects are being performed to achieve its real position of herbal medicine and herbal plants [12].

The era of the development of Islamic medicine in Iran can be traced back to the time when the book "zakhireh Kharazm Shahi” By Seyed Esmaeel Jorjani. This Iranian scientist created an enormous movement in the publication of medical texts in the Islamic civilization of the time and wrote his book in Farsi [13].

Iranian medical scientists had two distinct stages in participation in advancement of medical sciences: 1) the age of translation, from 750-900 AD, when many graduates of Gondi Sapur translated the corpus of Galenic and Hippocratic works; and 2) The golden age of creativity, from 900-1100 $\mathrm{AD}$, that was the era of Iranian world stars in pharmacology and pharmacy such as Rhazes (850-932) and Avicenna (980-1037). In their period about forty different pharmaceutical dosage forms were used and different kinds of extraction and preparing herbal medicines were developed [10] [13].

\section{Results}

The results of the research indicate that Islamic thinkers, using the results of research by scientists of natural and botanical sciences of other nations, especially Greece, founded the botanical sciences and herbal medicine in Islamic civilization. But they did not stop at this stage, with self-belief and innovation, they were interested in the growth and development of this science in different fields, and in some fields, due to outstanding scientific achievements, they were the bearers of overtaking others and turned into references for European scholars.

Historical evidence shows that Muslims have been trying to teach botany and compile books on medicinal herbs. They initially translated the translations of Dysfrides and Jalinus, and Indian books, and then converted them to research and compilation of the work in this field. For example, Mohammad bin Zakaria Razi not only had studies on medicinal herbs, but also about the famous pharmacology, and he introduced about 630 medicinal herbs in the twenty-first volume of his al-Hawaii book.

Among them are the following:

1) Writing a comprehensive botanical treatise and mentioning new species beyond the findings of the Uninean, along with the synonyms of each plant in various Arabic, Greek, Syriac, Hebrew languages ...

2) Compilation of the first botanical encyclopedia in Islamic civilization and superior to Greek examples.

3) Painting and imaging of plant growth stages on scientific trips.

4) Measuring the amount of drug adherence to professional ethics. 
5) Creating diverse vegetation gardens and farms for research purposes.

6) Pioneering the foundation of pharmacology and pharmacy in the modern way.

\section{Conflicts of Interest}

The authors declare no conflicts of interest regarding the publication of this paper.

\section{References}

[1] Hussain, N.S. (1980) Science and Civilization in Islam. Ahmad's Translation Is Slow. Kharazmi Publishing House, Kharazmi.

[2] Porter, R. (1999) The Greatest Benefit to Mankind: A Medical History of Humanity (The Norton History of Science). W. W. Norton \& Company, New York City, New York, 90-100.

[3] Ackerknecht, E.H. (1973) Therapeautics, from the Primitives to the 20th Century. Hafner Press, New York.

[4] Sepehri, Y. (2018) A Study on the Development and Growth of Agricultural Sciences in Islamic Civilization: Botany and Medicinal Plants. Journal of Plant Production Research, 24.

[5] Halabi, A.A. (1986) The History of Islamic Civilization. Amir Kabir Publications, Tehran.

[6] Zarin, K.A.H. (1997) Islamic Workbook. Amir Kabir.

[7] Hakimi, M.R. (1985) Muslim Knowledge. Islamic Culture Publishing Office.

[8] Beck, E. (1992) Ahmed. History of Hospitals in Islam. Translation: Dr. Noorullah Kasai. First Edition. Scientific and Cultural Publications.

[9] Zidane, G. (1990) The History of Islamic Civilization. Translation: Jewel of the Word. Amir Kabir.

[10] Fallah-Hoseini, H., Fakhrzadeh, H., Larijani, B. and Shikhsamani, A. (2006) Review of Anti-Diabetic Medicinal Plant Used in Traditional Medicine. Journal of Medicinal Plants, 5, 1-8.

[11] Nikbakht, A. and Kafi, M. (2004) The History of Herbal Medicine and Medicinal Plants in Iran. Proceeding of the 8th International Plant-People Relationship Symposium (IPPS), Hyogo, Japan.

[12] Nikbakht, A., Kafi, M. and Haghighi, M. (2008) The Abilities and Potentials of Medicinal Plants Production and Herbal Medicine in Iran. Acta Horticulturea, 7, 259-262. https://doi.org/10.17660/ActaHortic.2008.790.38

[13] Sharafzadeh, S. and Alizadeh, O. (2012) Some Medicinal Plants Cultivated in Iran. Journal of Applied Pharmaceutical Science, 2, 134-137. 